\title{
Geology of the Patharkhola area, Almora District, Uttarakhand (India): with special reference to the lithology and field relation
}

\author{
Haritabh Rana and Harel Thomas* \\ Department of Applied Geology, School of Engineering and Technology \\ Doctor Harisingh Gour Vishwasvidyalaya, Sagar (M.P.), India, 470003
}

\begin{abstract}
The Patharkhola area (longitude $79^{\circ} 09^{\prime} \mathrm{E}$ to $79^{\circ} 17^{\prime} 56^{\prime \prime} \mathrm{E}$ and latitude $29^{\circ} 47^{\prime} 42^{\prime \prime} \mathrm{N}$ to $29^{\circ} 56^{\prime} 69^{\prime \prime} \mathrm{N}$ ) covering an area of about 125 square Kms situated in Almora District, Uttarakhand forming a part of the Almora Nappe has been selected for the detailed geological mapping at an scale of $2 \mathrm{~cm}$ equal to $1 \mathrm{Km}$. The rocks mainly include phyllites, schists and gneisses forming an anticlinal structure showing phyllites in the NW, $\mathrm{S}$ to SW and in the western part of the area, while the schists occur in the folded outcrop pattern in between both the limbs of the fold and the gneisses occur in the core of the fold. Although thin quartzitic bands has also been noticed interbedded with phyllites and schists. Several transverse faults have been noticed in the area under investigation which has been demarcated in the map.
\end{abstract}

Key words: Lithology, field relation, Patharkhola, Kumaun Lesser Himalaya

Received: 5 May 2018

Accepted: 17 June 2018

\section{INTRODUCTION}

Himalaya, the youngest and loftiest mountain ranges, forming the extra-peninsular part of the Indian subcontinent, has attracted people since times immemorial. It runs along a grand arc, convex to the south, generally in a WNW-ESE direction between $27^{\circ}$ and $36^{\circ}$ latitudes for a total length of $2500 \mathrm{Kms}$. The Kumaun-Garhwal Lesser Himalaya, lies in between two tectonic plates - The Main Boundary Fault (MBF) in the south and the Main Central Thrust (MCT) in the north have suffered intense deformation in response to the various tectonic episodes which made it extremely difficult to establish a common stratigraphic and tectonic order. The area under investigation is one such part of the Lesser Himalaya which is still lacking in the fundamental geological records and leaves behind many unsolved problems. Some earlier classic works and recent researches, which reflect the regional picture of the Kumaun-Garhwal Lesser Himalaya in general, and the areas around Patharkhola in particular, have been considered in this study. An attempt has been made by the author to describe the regional geology of the Dudhatoli ranges on the basis of the long traverses taken by him and on the previous works in the Kumaun Lesser Himalaya. A detailed work was carried out by Medlicott $(1864,1876)$ who gave the first geological classification of the rocks of the Kumaun-Garhwal Lesser Himalaya. Later on, Oldham $(1883,1888)$ and Middlemiss (1885, 1887) mapped western part of the Kumaun-Garhwal Lesser Himalaya and described its geology. The KumaunGarhwal Himalaya have been divided into six major tectonic units from south to north, viz. the Autocthonous zone, Krol

*Corresponding author

Email: harelthomas@gmail.com (H. Thomas)
Nappe, Garhwal Nappe, Main Himalayan Ranges, Granitic Zone (North of Himalayan ranges) and the Tethys Zone by Auden (1937).

\section{REGIONAL GEOLOGY}

The rocks of the Kumaun and Garhwal Lesser Himalaya have been subjected to repeated phases of tectonic movements (Auden 1937; Sarkar et al. 1965; Gairola 1966, 1975, 1976; Krishnan 1960; Powar 1970, 1971; Mehdi et al. 1972; Kumar and Pande 1972, 1975; Kumar and Agarwal 1975; Valdiya 1962, 1980a, 1980b, 1981, 1983, 2016; Gairola and Srivastava 1982; Sharma and Sinha 1972, 1973; Thomas and Thomas 1992; Srivastava and Thomas 1999, 2002; Thomas and Thomas 2003; Srivastava et. al. 2003) which has resulted in a very complex geology. The rocks of the Dudhatoli Group (Mehdi et al. 1972) are exposed in the Patharkhola area. The 'Inner Schistose Series' (Middlemiss 1885, 1887) or the 'Metamorphic and Crystalline Nappe' Tectonic zone of the Lesser Himalaya (Pande 1974) forms a distinct structural unit which has witnessed multiple deformation and polymetamorphism. These rocks form extensive nappe sheets or occur as small outliers, thrust over the sedimentary sequence of the Krol Nappe (Auden 1937) in the southern part and the Garhwal Group (Jain 1971) in the northern part, and at places directly over the autochthonous Simla Slates (Kumar et al. 1974). These topmost nappe sheets are known by different names depending upon the locality and workers. In the Kumaun and Garhwal regions, there are two major outliers of the crystalline rocks, where the southern outliers have been named as Garhwal Nappe (Auden 1937) and the Northern outlier as Dudhatoli-Almora Nappe (Heim and Gansser 1939). The Dudhatoli Crystallines (Auden 1937) extend from Garhwal in WNW to Kumaun in ESE. Mehdi et al. (1972) included the Mandhali, Chandpur and Nagthat 
formations, and the Dudhatoli-Almora crystallines under a newly constituted group named the Dudhatoli Group where the Dudhatoli-Almora crystallines are the topmost horizon. Fuchs and Sinha (1978) considered it as Chail Nappe. Auden (1937) considered the Dudhatoli Crystallines to be the metamorphic equivalents of the Chandpur Series (Auden 1934) which overlies the Mandhalis (Auden 1937). Rocks of the Dudhatoli Group have been considered to be of Precambrian age (Auden 1937; Heim and Gansser 1939; Valdiya 1962; Mehdi et al. 1972; Kumar et al. 1974). In Kumaun Himalaya, the Munsairi Gneisses of Almora Group were dated as $1830 \pm 200 \mathrm{Ma}$ (Bhanot et al. 1977). The Patharkhola (Longitude $79^{\circ} 09^{\prime} \mathrm{E}$ to $79^{\circ} 17^{\prime} 56^{\prime \prime} \mathrm{E}$ and latitude $29^{\circ} 47^{\prime} 42^{\prime \prime} \mathrm{N}$ to $29^{\circ} 56^{\prime} 69^{\prime \prime} \mathrm{N}$ ) covering an area of about 125 square kms is situated in District Almora, Uttarakhand and can be approached by road from Kathgodam which is the nearest railway station (Fig. 1). To understand the regional geology of the Kumaun Himalaya, authors have taken traverses from Kathgodam-Ranikhet to Patharkhola and Ramnagar-Bhikiyasen to Patharkhola. After having an idea of the regional picture of the Kumaun Himalaya, long traverses around Patharkhola were taken to broadly outline the various lithological units of the area and intensive geological field work was carried out along road cuttings, streams and foot paths, and as far as possible mapping was done (Fig. 1). Some parts of the area have remained inaccessible because of the paucity of any approach. Moreover, at certain places, either the rocks were covered with vegetation or were exposed on almost vertical cliffs rendering the study of the outcrops impossible. A map (Fig. 1) was prepared on the scale of $2 \mathrm{~cm}$ to $1 \mathrm{Km}$, enlarged from the Survey of India toposheet No 53O/1.

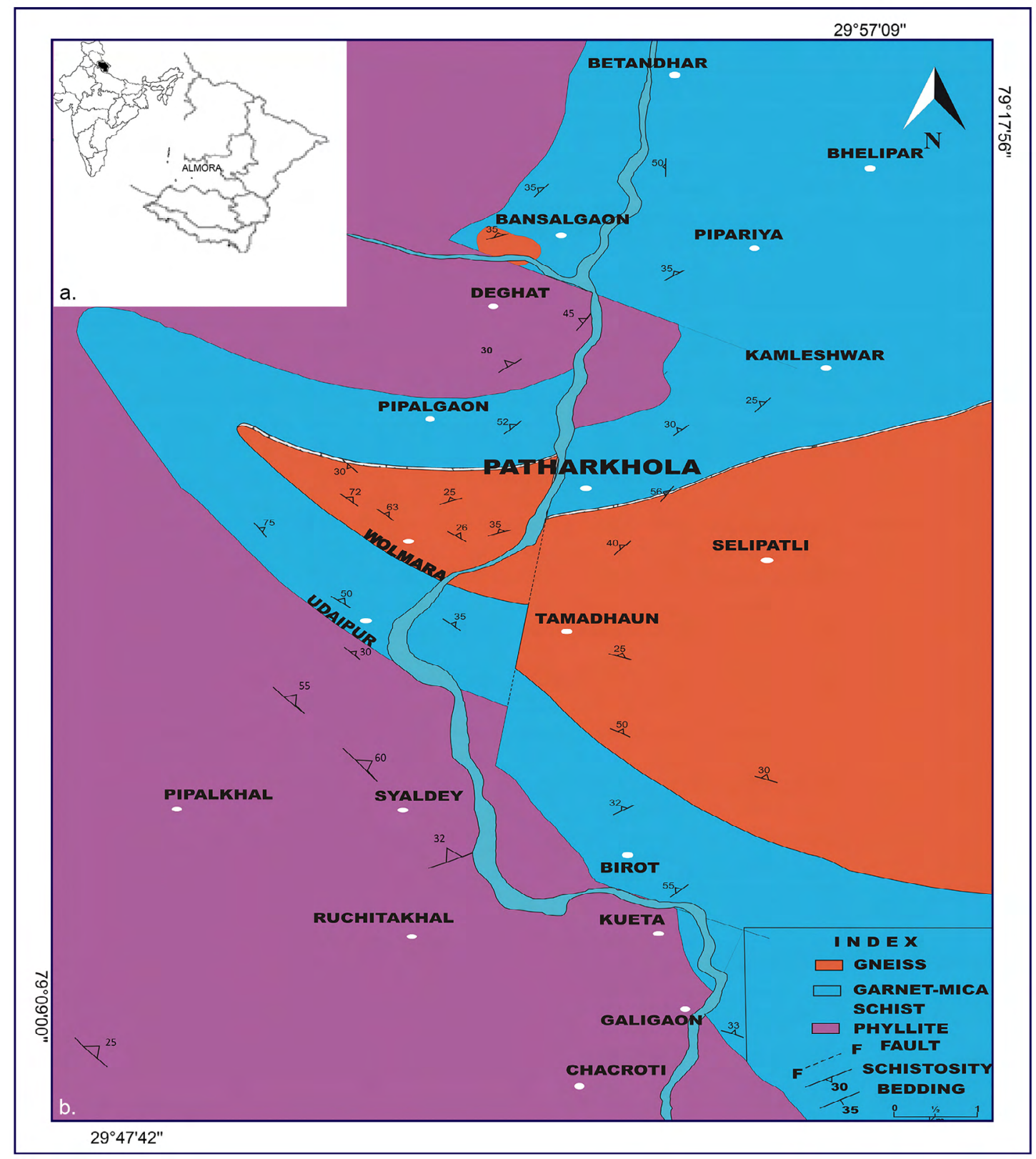

Fig. 1: (a). Location and, (b). Detail geological map around Patharkhola, Kumaun Lesser Himalaya, Uttarakhand, India (modified after Thomas and Thomas 1992). 
The area around Patharkhola forms the southern limb of Dudhatoli Syncline where the Dudhatoli-Almora Crystallines (Heim and Gansser 1939) and Phyllites (Kumar et al. 1974; Thomas and Thomas 2003) are exposed. An attempt has been made to describe the geological settings and the distribution of the lithological units in the area around Patharkhola (Fig. 1), which is largely controlled by the structure and its topography. The lithological units vary in their thickness and due to intermittent outcrop, partly covered by the alluvial soil and dense vegetation; it is difficult to show each individual unit on the geological map. Hence, individual units are grouped together into three major lithounits i.e phyllites, schists and gneisses for representation on the geological map (Fig. 1). However, the quartzites which are interbedded with the phyllites and the schists of the area have been described separately. On the basis of the present and earlier works, a lithostratigraphic succession as shown in Table. 1 has been established.

Table 1: Lithostratigraphic succession of the Patharkhola area, District Almora, Uttarakhand, India.

\begin{tabular}{|l|l|l|l|}
\hline Group & Formation & Member & Age \\
\hline \multirow{4}{*}{$\begin{array}{l}\text { Dudhatoli } \\
\text { Group }\end{array}$} & $\begin{array}{l}\text { Dudhatoli- } \\
\text { Almora } \\
\text { Crystallines }\end{array}$ & $\begin{array}{l}\text { Gneisses } \\
\text { Schists - Garnet } \\
\text { Mica Schist } \\
\text { with interbedded }\end{array}$ & \\
\cline { 3 - 4 } & Phyllites & Flaggy Quartzites & $\begin{array}{l}\text { Early } \\
\text { Precambrian }\end{array}$ \\
& & $\begin{array}{l}\text { Phyllites- } \\
\text { Phyllites with } \\
\text { interbedded } \\
\text { Quartzites }\end{array}$ & \\
& & & \\
\hline
\end{tabular}

\section{Phyllites}

Phyllites are well distributed in the area, exposed in the NW, S to SW and in the western part of the area (Fig. 1). The phyllites are grey, greenish grey, brownish and greyish green in colour. They are generally fine grained and thinly foliated and at places, become compact and siliceous. Increase in the silica percentage (Fig. 2a) gives a quartzitic appearance to these phyllites. Due to fine grained nature of phyllites, it is difficult to identify the mineralogical composition in the field, but in general the phyllites are composed of quartz, chlorite, feldspar and mica. Phyllites in this region are interbedded with medium to fine grained quartzite bands measuring up to 2 to 10 meters in thickness. These phyllites are characterised by well developed schistosity. At places, the colour bands in siliceous phyllites shows bedding planes (S1). Near the fault planes, the phyllites are crushed and powdery. Best exposure of crushed phyllites can be observed near village Ruchaikhal, Syaldey and Deghat (Fig. 2b). Phyllites are commonly traversed by quartz veins which run parallel to schistosity. These phyllites exhibit well developed crenulations (Fig. 2c) and shear joints. The phyllites of the area under investigation show a strike variation from NNE-SSW to WNW to ESE dipping towards northern and southern directions.

\section{Schists}

In the area under study, schists occur in a folded outcrop pattern and are characterised by their physical and mineralogical characters. Depending upon the biotite, muscovite and/or chlorite content, they exhibit a variation in colour from pinkish brown, dark brown, light grey to greyish green. Schistosity (S2) is defined by the preferred orientation of the flaky minerals and are characterised by one or two sets of crenulations. The rock is friable in nature but at places increased percentage of quartz and feldspar imparts compaction. Thin bands of micaceous quartzites of $1 \mathrm{~cm}$ to $20 \mathrm{~cm}$ in thickness are also present within the schist. The schists of the area are characterised by the presence of garnet which ranges in size from $1 \mathrm{~mm}$ to $2 \mathrm{~mm}$ in hand specimen. Slightly bigger sized garnets (about $4 \mathrm{~mm}$ ) are exposed in the NE of Udaipur and south of Wolmara and along river Bino. The quartz veins occur parallel to schistosity and at times shows folded structure.

\section{Gneisses}

Medium to coarse grained porphyroblastic augen gneisses and medium grained foliated gneisses are very well exposed in the area under study. The foliated gneisses are hard and compact and their colour varies from greyish white to dirty white. Biotite and muscovite define the foliation whereas variation in the mineralogical composition imparts compactness and gives colour to these gneisses. Randomly oriented tourmaline laths of 3 to $4 \mathrm{cms}$ in length have been observed near the Tamadhaun Primary School (Fig. 2g). Augen gneisses (Fig. 2e-f) are well exposed between village Patharkhola and Wolmara where it is in contact with the garnet bearing schists. Plagioclase porphyroblasts wrapped around by grey to greenish mica have imparted augen nature to these rocks. The presence of the sigmoidal trace of foliation in between the two parallel planes i.e SC structure indicated the existence of shear zone in the foliated gneisses of the area. These shear sense indicators are very few in number varying in width from 1 to $15 \mathrm{~cm}$ in length. However, in the area no such large scale shear zone has been observed. Gneisses of the area are traversed by the NNE-SSW striking transverse fault. This transverse fault has brought the schist in contact with the gneisses near the Patharkhola village. Two or three set of joints have also been observed in this rock type.

\section{Quartzites}

Two varieties of quartzites interbedded with phyllites and schists of the area have been observed. The micaceous quartzites interbedded with mica schists of the area are well exposed in the Kamleshwar area. These quartzites mainly composed of quartz, muscovite and iron oxides. The micaceous minerals in the quartzites shows preferred orientation. These quartzites are thinly bedded and the individual thickness of the individual beds varies from 1.0 to $2.0 \mathrm{~cm}$, constituting a thin band of quartzite of about 15 to $20 \mathrm{~cm}$. These quartzites represent beddings (S1) which is presumably parallel to (S2) of the garnet-mica schist. The strike of these quartzites varies 

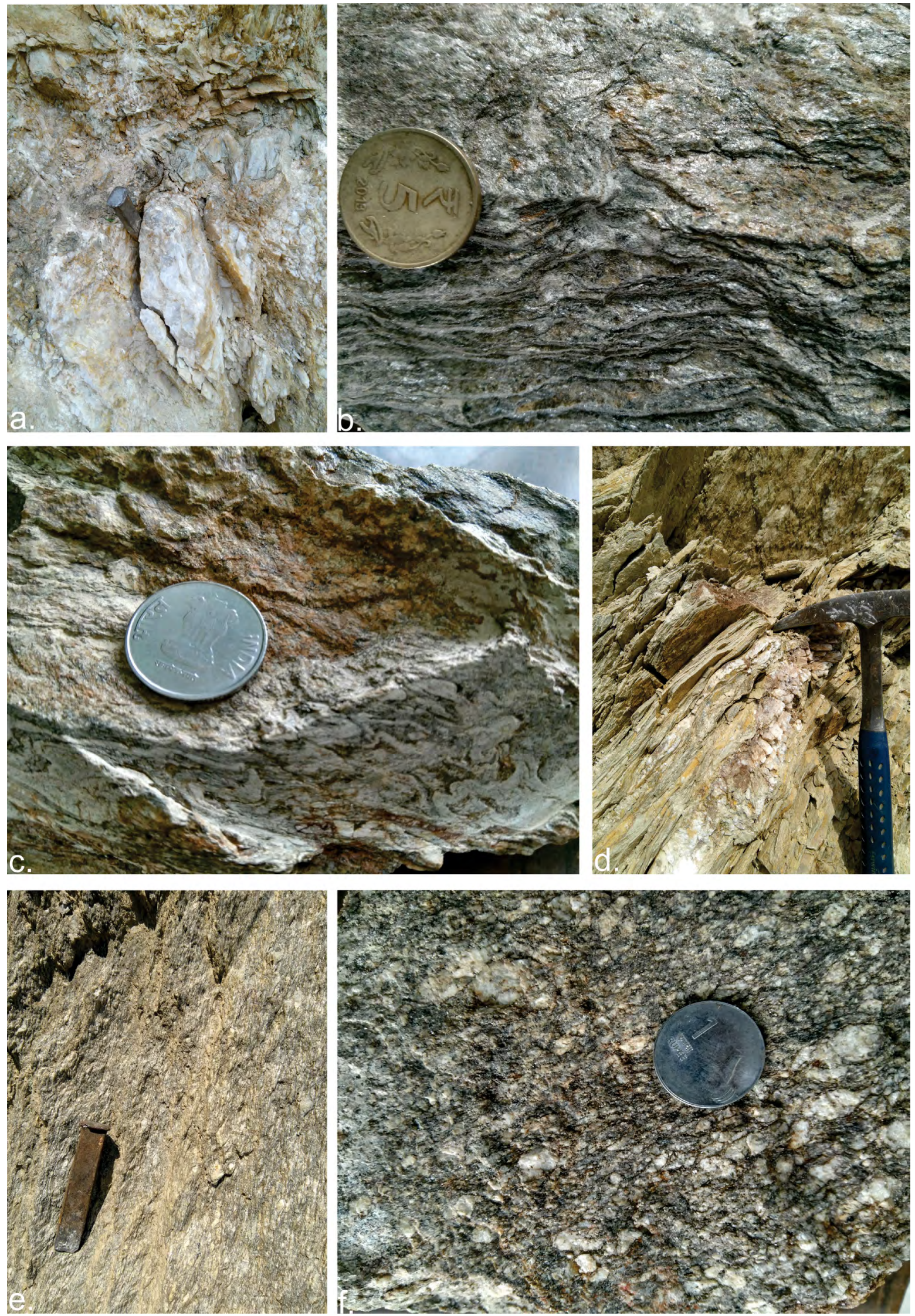

Fig. 2: (a). Quartz intrusion in phyllites at Syaldey, (b). Phyllites exposed at Ruchaikhal, (c). Well developed crenulations in phyllites exposed near Udaipur, (d). Phyllites exposed at Kueta, (e). Gneisses exposed at Wolmara, (f). Augen gneiss at Patharkhola, (g). Augen gneiss at Tamadhum. 


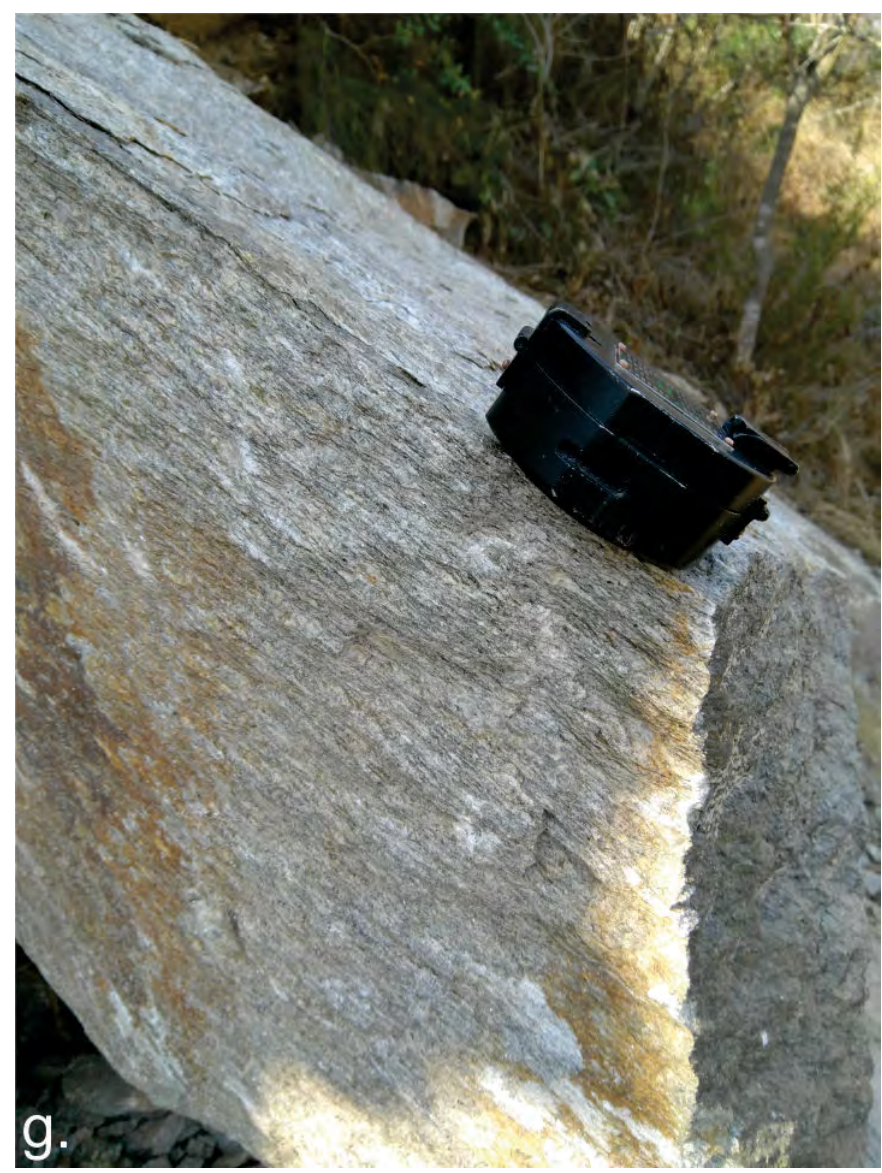

from NNE-SSW to WNW-ESE and it generally dip towards NW direction. The medium to fine grained white to dirty quartzites are interbedded with the phyllites of the area. The thickness of the individual bedding planes of these quartzites varies from 10 to $60 \mathrm{cms}$ constituting a thickness of these quartzites bands as 2 to 10 metres. These quartzites are also made up of quartz, muscovite and iron oxides.

\section{CONCLUSIONS}

The present area around Patharkhola lies in the southern limb of Dudhatoli Synform (Mehdi et al. 1972), in the north of the South Almora Thrust, in the Kumaun Lesser Himalaya. The area in general exhibits a typical Himalayan rugged topography and is traversed by river Bino. The rocks of the Dudhatoli Group exposed in the area exhibits variable amount and direction of dip where bedding (S1) is parallel to the schistosity (S2). The rocks of the Dudhatoli Group are represented by phyllites, schists and gneisses while quartzites of non-mappable units are found interbedded with schists and phyllites. On the basis of present and earlier works, a lithostratigraphic succession as shown in Table. 1 has been established.

\section{ACKNOWLEDGEMENT}

Authors are thankful to Department of Applied Geology, Dr. Harisingh Gour Vishwasvidyalaya, Sagar (M.P.) and Department of Science and Technology, New Delhi, India for providing facilities as PURSE- Phase II for conducting present research work.

\section{REFERENCES}

Auden, J.B., 1934. The Geology of the Krol Belt., Rec. Geol. Surv. India., 67, v. 4, pp. 357-454.

Auden., J.B., 1937. Structure of the Himalaya in Garhwal., Rec. Geol. Surv. India., 71, v. 4, pp. 407-433.

Bhanot, V.B., Singh, V.P., Kansal, A.K., and Thakur, V.C., 1977. Early Proterozoic Rb-Sr whole-rock age for Central Crystalline Gneiss of Higher Himalaya, Kumaun. Geol. Soc. India, v. 18(2), pp. 90-91.

Fuchs, G., and Sinha, A., 1978. Geology and Tectonics of Garhwal and Kumaun Lesser Himalaya, Jahrb. der Geol. Bund., v. 121, pp. 219-241.

Gairola, V.K., 1966. Refolding in the tectonite of the Kausani area, District Almora. U.P. Publ. Adv. Cent. Stud. Geol. (P.U) Chandigarh., v. 3, pp. 101-106.

Gairola, V.K., 1975. On the petrology and structure of the Central Crystallines of the Garhwal Himalaya. Him. Geol., v. 5, pp. 455-468.

Gairola, V.K., 1976. Deformed Nummulites from Dugadda area, Garhwal Himalaya. Bull. Earth Sci., v. 4-5, pp. 69-71.

Gairola, V.K., and Srivastava, H.B., 1982. Structure and deformation history of a part of Dudhatoli Synform around Srinagar, District Pauri Garhwal, U.P. Mitt. Geol. Ist. ETH Zurich, Neue Folge, 239a, pp. 106-108.

Heim, A., and Gansser, A., 1939. Central Himalayas geological observations of the Swiss expeditions, 1936., Mem. Sco. Helv. Sci. Nat, v. 73(1), pp. 1-245.

Jain, A.K., 1971. Stratigraphy and tectonics of Lesser Himalayan region of Uttarkashi, Garhwal Himalaya., Him. Geol., v. 1, pp. 25-57.

Krishnan, M.S., 1960. Precambrian stratigraphy of India., 21st Int. Geolo. Cong. Proc. v. 91, pp. 95-107.

Kumar, R., and Pande. I.C., 1972. Deformation of the rocks of Simla Hills., Geol. Rundach., v. 62(2), pp. 430-441.

Kumar, R., and Pande, I.C., 1975. Deformation of the rocks in the Blaini type area., Bull. Indian Geol. Asso., v. 8(2), pp. 143-150.

Kumar, G., Prakash, G., and Singh, K.N., 1974. Geology of the Deoprayag-Dwarahat area, Garhwal, Chamoli and Almora Districts, Kumaun Himalaya, Uttar Pradesh. Him. Geol, v. 4, pp. 323-347.

Kumar, G., and Agarwal, N.C., 1975. Geology of the SrinagarRudraprayag area (Alaknanda Valley), Chamoli, Garhwal and Tehri-Garhwal District, Kumaun Himalaya, U.P., Him. Geol., v. 5, pp. 29-59.

Medlicott, H.B., 1864. On the geological structure and relations of the southern portion of the Himalaya, a range between river Ganga and Ravee., Mem. G.S.I., v. 3(2), pp. 1-212.

Medlicott, H.B., 1876. Notes upon the Sub-Himalayan series in the Jammu hills., Rec. G.S.I., v. 97, p. 31

Mehdi, S.H, Kumar, G., and Prakash G., 1972. Tectonic evolution of the eastern Kumaun Himalaya: a new approach., Him. Geol., v. 2, pp. 481-501.

Middlemess, C.S., 1885. A fossiliferous series in the Lower Himalaya in Garhwal. Rec. Geol. Surv. India. v. 18, pp. 73-77.

Middlemess, C.S., 1887. Crystallines and metamorphic rocks of the Lower Himalaya, Garhwal and Kumaun., Rec. Geol. Surv. Indian, v. 20(3), pp. 134-143.

Oldham, R.D., 1883. Note on geology of Jaunsar and the Lower Himalaya. Rec. Geol. Surv. India, v. 16(4), pp. 193-198.

Oldham, R.D., 1888. Some notes on the geology of north west Himalayas. Rec. G.S.I., v. 12, pp. 149-167.

Pande, I.C., 1974. Tectonic interpretation of the Geology of Nainital area. Him. Geol, v. 4, pp. 532-546.

Powar, K.B., 1970. Multiphased mesoscopic folding in metasediments of Almora area, Kumaun Himalaya. Publ. Cent. Adv. Stud. Geol. P.U. Chandigarh, v. 7, pp. 61-67.

Powar, K.B., 1971. Structural analysis of the Almora area. Jour. Univ. Poona. Sci and Tech. Sec. v. 40, pp.103-110. 
Sarkar, S.N., Reddy, V.S., and Nair, P.K.R., 1965. Tectonic pattern of a part of Almora nappe zone around Almora, Dr. D.N. Wadia commemorative vol. India Min. Geol. Metal. Inst. India., pp. 668-702.

Sharma, R.P., and Sinha, A.K., 1972. Stratigraphy and structure of Ranikhet area, Kumaun Himalayas. Proc. Indian Sci. Cong., 59.

Sharma, R.P., and Sinha, A.K., 1973. Geology of Ranikhet area, Kumaun Himalayas. Proceedings of the Indian Nat. Sci. Aca., Physical sciences, v. 39, pp. 137.

Srivastava, H.B., and Thomas, T., 1999. Structure and deformation history of a part of Dudatoli Crystalline around Tamadhaun District, Almora. Bull. Indian Geol. Asso., Chandigarh. v. 32(2), pp. 1-14.

Srivastava, H.B., and Thomas, T., 2002. Strain and buckling analysis of single layer folds. In: Proc. on geodynamics and environment management of Himalaya, pp. 117-129.

Srivastava, H.B., Thomas, T., and Tripathi, R.N., 2003. A petrographical approach to strain estimation in deformed rocks; example from granitic gneisses of a part of Almora Synform Garhwal Lesser Himalaya. Mem. Geol. Soc. India, v. 52, pp. 427-446.
Thomas, T., and Thomas, H., 1992. Fold flattening and strain studies in a part of Almora Crystalline Zone, around Tamadhaun Kumaun Himalaya. Indian Mining and Engineering Jour., pp. 5-7.

Thomas, T., and Thomas, H., 2003. Fourier shape of fold developed around Tamadhaun District Almora using a computer program, Gond, Geo. Mag. v. 7, pp. 169-175.

Valdiya, K.S., 1962. Outline of the stratigraphy and structure of the southern part of Pithoragarh District, U.P. ., Quart. Jour. Geol. Min. Met. Soc. India, v. 35, pp.167-180.

Valdiya, K.S., 1980a. Stratigraphic scheme of the sedimentary units of the Lesser Kumaun Himalayas., In Stratigraphy and correlation of Lesser Himalayan Formation (Ed. K.S. Valdiya and S.B Bhatia), Hindustan Publ. (India), Delhi, pp.7-48

Valdiya, K.S., 1980b. Geology of the Lesser Kumaun Himalaya. W.I.H.G., Dehradun. pp. 68-89.

Valdiya, K.S., 1981. Tectonics of the central sector of the Himalaya. Zagros Hindu Kush Himalaya geodynamic evolution. In H.K. Gupta and F.M. Delany (Eds.): Geodynamic series. v. 3, pp. 87-110.

Valdiya, K.S., 1983. Lesser Himalayan geology: crucial problems and controversies. Current Science, pp. 839-857.

Valdiya, K.S., 2016. The making of India, Springer, 924 p. 